\title{
Philosophical meaning of the myth of pregnant and nursing mothers at Dawuhan village, Banyumas
}

\author{
${ }^{1}$ Astiana Ajeng Rahadini* and ${ }^{2}$ Rahmat \\ Universitas Sebelas Maret \\ Surakarta, Indonesia \\ *Corresponding author \\ Email: ajengrahadini@gmail.com
}

\begin{abstract}
Traditional culture underlying a wide range of behavior and deeds of a society and gave birth to a variety of oral literature as well as myth. The myth that developed and still surviving in public life of Java among other myths related to pregnant and nursing mothers. This research is under a descriptively qualitative method supported by field research method along with un-depth interviews in Dawuhan village of Banyumas which is the village where the ancestors of Banyumas was buried. Through field observation and research method of interview to the trusted resource in Dawuhan village was obtained by results of research regarding the myth of pregnant and nursing mothers. This research finds some kinds of myths in relation to recommending and prohibition to perform an action that may harm the fetus, while the myth of breastfeeding mothers mostly prohibition and advice about foods that are consumed by the mother breastfeeding can harm the health of the baby.
\end{abstract}

Keywords: Myths of Java, pregnant women, nursing mothers, Banyumas

Received:

Revised:

Accepted:

Published:

17 May 2018

2 August 2018

30 August 2018

31 August 2018

\section{INTRODUCTION}

A particular way of life that can be seen in a society in the form of artistry, social organization, livelihood, language, or religion is called 'culture' (Masinambo, 1997:p.9). It described again about culture, that way of life comes to a few basic things of a society that is different from the other community. However, if it is said the possibility is also not different because there are similarities in some communities, for example related to the life cycle even though different in terms of the ordinance or a series of implementation nor the infrastructure used. For example, a woman's pregnancy selamatan ceremony in Javanese tradition held on gestational age 4 and 7 (Aldy dkk, 2013: pp.21-31).Similar ceremonies are also performed by Sundanese upon the gestational age of a woman entering the month to $2,4,7$, and 9 . That example shows cultural similarities of life cycle when a woman is pregnant 
with commemorating the age of content that aims to let women who are pregnant get salvation. In the meantime, the difference is in the age or month of pregnancy. So, a culture can be said to be different, similar, or the same between one community with other communities.

The culture of each society, though in reality it is said to be different, not the same or the similar. However, if there are the differences as well as the similarities seen as a uniqueness. Uniqueness-the uniqueness of a culture, can be determined by several factors like the ordinances, procession, infrastructure, tools, rationale, and the accompanying story. About the last, namely the story that accompanies a form of culture can be folklore, legends, and myths depending to the context of culture itself. For example, the tradition of Labuhan in the Javanese in Sleman influenced by legend; the tradition of cut hair for dreadlocks kids (bocah gimbal) in the Dieng area to visit based on the folklore of Kyai Kalodete; and a number of activities based on behavior or conduct in the Javanese influenced by myths such as the prohibition to marry in the month of Sura.

Based on the uniqueness of the story on that, then this study will examine one of them alone, that is a myth. Myth (Mitos) is a story of a nation about god and ancient heroes, contains interpretation about the origin of the universes, human, and the nation, contains deep meaning that explain in supranatural way (Tim Redaksi, 2008: p.922). The myth will be examined further are the myths surrounding pregnant and nursing mothers. It developed deliberately to strengthening the ideology (Zaidan dkk, 2007: p.57). The category of food for pregnant women and in the aftermath of the birth associated with a view culture about food is considered to be good so that should be consumed, and considered the impact of bad for the mother so that should be avoided. The food is considered to be able to provide the impact of bad commonly referred to as restrictions eat (Swasono, 1998). Restrictions (taboo) food is a ban to consume the kind of certain foods because there are a threat danger for them who broke it (Nugraheni and Dyah, 2014). If the restrictions not done will happen something bad for health of pregnant women and in the aftermath of the birth and considered deviate (Angraini, 2013: p.169). As for the problems in this research include any myth that accompanies pregnancy and a mother who is breastfeeding. This study will describe the myth of pregnant women and then analyze the philosophical meaning contained in it.

As for the place of implementation of the study in Dawuhan village, Banyumas. Dawuhan village is one of the villages in the Banyumas is a village where the ancestors of Banyumas, Banyumas Regent was buried as I, II, and Mangkubumen. It is also a village which was formerly a Kademangan, headed by demang. As the village is believed to ancestors as a final resting place, the villagers Dawuhan believe to preserve the variety of life belief of Javanese people, including myths. The purpose of this research is an inventory and definition in the interpretation of the myth of pregnant and nursing mothers.

This study use the myth theory. The myth is that a message containing a particular discourse and conveyed through speech (and written) (Roland 
Rahadini \& Rahmat, EduLite: Journal of English Education, Literature, and Culture Vol.3, No.2, August 2018, 188-195 DOI: http://dx.doi.org/10.30659/e.3.2.188-195

Barthes via Zaimar, 2015: p.403). So, it can be said that it is the myth of "orality" and presumably formed from a construction firm. Werner (2008: pp.47 - 53) gave opinions on occurrence and formation conditions of the myth. The presence of myths sourced from an imagination, created environmental and hereditary predisposition.

The myth comes in a community with three conditions. The first constructive imagination, which is considered as a description of people who are not scientific. Second, the stimulus that is feeling to nurture and maintain the myth. Third, persistent souls expression i.e. resistant of all time. From the Werner's opinion can be drawn the philosophy basis of the myth are imaginatively formed by society and maintained from generation to generation. Though, in the end some or many peoples perhaps will not believe it.

As for the function of myth for a society is mentioned by Sibarani (Fahmawati, 2013:p.299), namely moral and ethical attitudes relating to acts that are permitted and which are prohibited. The deed must be known and adhered to by all members in the community. With respect to acts that are allowed or prohibited, Herusatoto (2011: p.98) said that the act was influenced by a "power" that comes from the outside. The "power" that was translated by a Taslim (2013: p.593) as the relationship between man and nature as well as with a nonhuman creature that does not appear.

So, the myth based on its function was a warning to the public about the acts that may or may not do. In reality the society considers that restrictions are more affected by something that doesn't look or unexplained. When breached or not adhered to will cause certain consequences.

Based on its imaginatively, handed down orally, and its function as a controller action then myths need to be interpreted because use connotative language. This occurs because often the myth present in its elusive deal directly or logically. Therefore, it is necessary to use an approach to describe a myth. The intended approach is the approach to hermeneutics. Hermeneutics is aiming to get an understanding through definition (making sense) of language (Alwasilah, 2010: p.125 - 127). This is in accordance with the thoughts of Levi Strauss who considered the myth as a language, said to be known by the community (Taum, 2018: p.1). Furthermore, Indraningsih (2011: p.120) mentions the terms of hermeneutics is a creative interpretation. That is, the meaning obtained through the dismantling of the riddle.

\section{METHOD}

The method of this research is the workings of a study. Therefore, the necessary steps for a systematic research can be carried out as appropriate. As for the methods used in the study of the myths of pregnant and nursing mothers in the Dawuhan village of Banyumas include observation, field and search the data in the form of an interview against elders named Wartinah or more familiarly saluted by Nini Genuk which in the study was used as the main informant. 
The main informant profession as a baby shaman. In addition, conducted the interview anyway against the five men women (Ruby, Warni, Sri, Sukesi,and Rodiah) that serve as a comparison against the results of the interview against the main informant. Five women were selected randomly. The results of interviews collected, recorded, and then presented in this study.

This research used descriptive qualitative method, which aims to describe the object of research as it is. Data collection techniques use observation and interview techniques. Interviews were conducted directly to informants. Meanwhile, data analysis techniques through data collection, data reduction, data presentation, and conclusion.

The object of the study consisted of six women. One person as the main informant is a 60-year-old traditional baby shaman. Other informants consisted of five women who were residents of Dawuhan Village where two of them were elders who were respected by the community.

\section{RESULTS AND DISCUSSION}

The following data will be presented the results of the interviews of the informant who comes from the Dawuhan village. First data is the myth about pregnant women. Meanwhile, the second is data myths about nursing mothers. The data presented myth and logic interpretations. The first myth is that the myths about prohibition and the argument against pregnant women.

Table 1. The Results of the Interview

\begin{tabular}{|c|c|}
\hline Myth Perspective & $\begin{array}{c}\text { Interpretations } \\
\end{array}$ \\
\hline $\begin{array}{l}\text { Pregnant women are prohibited } \\
\text { from closing the small holes, like } \\
\text { the hole of the door, ant holes, and } \\
\text { ventilation. }\end{array}$ & $\begin{array}{l}\text { This is a figuratively myth. This means that } \\
\text { the hole is equated with labor. If a pregnant } \\
\text { mother close holes like the hole of the door, } \\
\text { ant holes, and then vent the meaning there's } \\
\text { consequences will be borne by pregnant } \\
\text { women, that is believed will complicate the } \\
\text { process of the birth of birth because the road } \\
\text { is closed. }\end{array}$ \\
\hline $\begin{array}{l}\text { Pregnant women are forbidden to } \\
\text { eat the banana dhempet. }\end{array}$ & $\begin{array}{l}\text { Dhempet has the meaning of 'two stuff or more } \\
\text { adhere' and other meaning 'grow together and } \\
\text { adhere' (Poerwadarminta, 1939:104). Banana } \\
\text { dhempet be an allusion to a fetus conceived } \\
\text { could be conjoined twins. }\end{array}$ \\
\hline $\begin{array}{l}\text { Pregnant women should carry tools } \\
\text { or weapon. }\end{array}$ & $\begin{array}{l}\text { In some areas there are in the form of scissors, } \\
\text { in other areas in the form of onions which were } \\
\text { fastened on the pins and then patch in clothes. } \\
\text { Purpose is to make protected from the spirits. } \\
\text { Based on the context it can be concluded that } \\
\text { pregnant women carrying a weapon is as a } \\
\text { form of protection against hazards that may } \\
\text { arise at any time. For example, when all of a } \\
\text { sudden have to protect himself from wild } \\
\text { animals or poisonous animals. }\end{array}$ \\
\hline $\begin{array}{l}\text { Mother and father of the fetus } \\
\text { forbidden to kill animals, thou }\end{array}$ & $\begin{array}{l}\text { This is myth with figurative meaning. That } \\
\text { hurt animals will cause the fetus to become }\end{array}$ \\
\hline
\end{tabular}


Rahadini \& Rahmat, EduLite: Journal of English Education, Literature, and Culture Vol.3, No.2, August 2018, 188-195 DOI: http://dx.doi.org/10.30659/e.3.2.188-195

\begin{tabular}{|c|c|}
\hline be consumed. & disabled. \\
\hline $\begin{array}{l}\text { Pregnant women are advised to } \\
\text { drink young coconut water. }\end{array}$ & In order for the baby's skin clean and white. \\
\hline $\begin{array}{l}\text { Pregnant women are advised to } \\
\text { consume a lot of water decoction of } \\
\text { soybean. }\end{array}$ & In order for the baby to grow thick hair. \\
\hline $\begin{array}{l}\text { Pregnant women are advised to } \\
\text { drink coconut oil or klentik oil. }\end{array}$ & In order for smoothly birth. \\
\hline $\begin{array}{l}\text { Pregnant women were forbidden to } \\
\text { sew. }\end{array}$ & $\begin{array}{l}\text { If a pregnant woman performs the activity of } \\
\text { sewing, then feared may hurt the stomach } \\
\text { when pregnant mothers in conditions of tired } \\
\text { and no concentration. }\end{array}$ \\
\hline $\begin{array}{l}\text { Pregnant women are prohibited } \\
\text { from scratching the stomach. }\end{array}$ & $\begin{array}{l}\text { Some expectant mothers will feel his stomach } \\
\text { itch. It is believed because the fetus is growing } \\
\text { hair. So, not to be carded. If the scratch will } \\
\text { leave scars and adverse fetal effect feared. }\end{array}$ \\
\hline $\begin{array}{l}\text { Pregnant women with the age of the } \\
\text { womb seven months were forbidden } \\
\text { to buy baby equipment. }\end{array}$ & $\begin{array}{l}\text { This is a figure of speech myth. The activity of } \\
\text { buying baby equipment before the time the } \\
\text { baby birth is believed to cause the baby was } \\
\text { born premature. }\end{array}$ \\
\hline $\begin{array}{l}\text { In case of earthquake or lindhu } \\
\text { (small frequent of earthquake), } \\
\text { pregnant women should get into the } \\
\text { space under the bed and rubs the } \\
\text { belly with warm cleansing powder. }\end{array}$ & $\begin{array}{l}\text { In order for a baby in the belly is not confused } \\
\text { and keep warm. }\end{array}$ \\
\hline
\end{tabular}

Based on the above data in table 1, it can be summed up the myth of the pregnant women in the Dawuhan village in general consists of the restrictions and recommendations. Of the eleven data, the myth with amount restrictions classification more than the myth with the advice classification. In the meantime, the myth with respect to breastfeeding mothers can be seen from the table below.

Table 2. Myths in Dawuhan

\begin{tabular}{ll}
\hline \multicolumn{1}{c}{ Myth } & \multicolumn{1}{c}{ Interpretations } \\
\hline $\begin{array}{l}\text { New mothers who give birth should } \\
\text { be frequent-often sit on a warm } \\
\text { cleansing powder. }\end{array}$ & $\begin{array}{l}\text { So the wound quickly dries up. So the wound } \\
\text { quickly dries up. }\end{array}$ \\
\hline $\begin{array}{l}\text { New mothers who give birth are told } \\
\text { to eat keleman (chicken liver). }\end{array}$ & $\begin{array}{l}\text { Foods such as chicken livers are believed to be } \\
\text { able to recover post-birth, because at the time } \\
\text { of giving birth, a woman took out a lot of } \\
\text { power. }\end{array}$ \\
\hline $\begin{array}{l}\text { Nursing activities must be performed } \\
\text { interchangeably because of the }\end{array}$ & $\begin{array}{l}\text { The right breast is believed to absorb nutrients } \\
\text { fontent of ASI (breast milk) on both } \\
\text { breast is different. ASI on right } \\
\text { breast should be sucked prior left } \\
\text { breast. }\end{array}$ \\
\hline Nursing mothers are forbidden to eat & Because ASI (breast milk) would be fishy. \\
\hline
\end{tabular}




\section{eggs.}

Nursing mothers are prohibited from eating chili sauce.

Nursing mothers are prohibited from drinking ice.

ASI that attaches or left on the baby's face should be licked by her mother.

When nursing mothers recently traveled far, before feeding returned the breast is washed with warm water first.

Nursing mothers are less smoothly ASI should be washed using warm cleansing powder and her tits combed using bamboowulung.

Nursing mothers must often drink jamu uyup-uyup (like herbal drink).
Because ASI (breast milk) would be spicy and the baby could be affected by diarrhea.

Because breast milk will be frigid and the baby will be runny.

In order not to cause panu (skin fungus).

Mother who feared traveling bring dirt and bad stuff that can be attached to the breast and fear sucked through breast milk.

Warm cleansing powder and bamboo wulung can unleash a discharge of breast milk. ASI less smoothly is possible because there are things unseen are annoying and can be addressed with bamboo wulung.

Jamu uyup-uyup derived from the juice of winged bean seeds, and turmeric are believed to be able to smoothen the breast milk.

Nursing mothers should use
weapons in the form of a small pair
of scissors embedded in the bottom
punch lanang sada so did not dare to disturb
of the baby bedding and use sada
lanang. Sadalanang is broom stick
made from palm tree leaf rib.
When nursing mothers throw away
the remaining water bath the baby and bad things in the baby.
then it should say "Ora mbuang
banyu tapi puyenge sebel si bayi".
That means do not throw away the
water but dispose of the bad things
that exist on the baby.
Nursing mothers should always
locked his son when the baby sleeps.
Locked is done by attaching a hand mothern the baby because it was locked by his
in pubic throughout diusapkan later
the body of a baby starting from
head to foot. locked is done three
times.

Based on the explanation above it conclude that myths about breastfeeding moms numbered fifteen. As for the motive of the myth that breastfeeding mothers in the form of recommendations and restrictions among others associated with food and drinks should not be consumed, for example, should not eat spicy sambal taste because it can cause the baby is exposed to diarrhea. Other foods like eggs that smells fishy when consumed will make breast milk into amis. Nevertheless, there are foods that are recommended to 
Rahadini \& Rahmat, EduLite: Journal of English Education, Literature, and Culture Vol.3, No.2, August 2018, 188-195 DOI: http://dx.doi.org/10.30659/e.3.2.188-195

be consumed that is chicken's liver. Meanwhile, the spill ASI stuck in a baby's face should be licked the mother because it is believed to not lead to panu. Though indeed, logically with the clean up of spills of breast milk in baby face baby face can make maintained clean.

\section{CONCLUSION}

Based on interview data obtained myths about expectant mothers there are eleven with details of two motives i.e. restrictions and recommendations related to the activities of the pregnant women that may harm the baby or not. Meanwhile, myths about breastfeeding mothers identified as many as ten myths, with restrictions and recommendations in which the majority of meals and beverages that should and should not be consumed. However, these myths may direct the community to perform actions. Such measures may include restrictions or recommendations when further construed to be found red thread that actually can be explained scientifically.

\section{REFERENCES}

Aldy, et al. (2013). Tradisi Mapati dan Mitoni masyarakat Jawa Islam."Prosiding the $5^{\text {th }}$ International Conference on Indonesian Studies "Ethnicity and Gobalization". pp. 21-31. Yogyakarta: Fakultas Ilmu Pengetahuan Budaya Universitas Indonesia.

Alwasilah, A. Chaedar. (2010). Filsafat Bahasa dan Pendidikan. Bandung: Sekolah Pascasarjana Universitas Pendidikan Indonesia and PT. Remaja Rosdakarya.

Angraini, D. (2013). Pantangan makan ibu hamil dan pasca melahirkan di Desa Bongkot Kecamatan Peterongan Kabupaten Jombang. Jurnal BioKultur, Volume II, Nomor 2, 167-178. Surabaya: Universitas Airlangga.

Fahmawati, A. (2013). Tradisi Lisan dan Pembangunan Karakter Bangsa: Melawan Krisis Moral dengan Nilai-Nilai Kearifan Lokal' dalam Folklore dan Folklife. Suwardi Endraswara, Pujiharto, Yoseph Yapi Taum, and Afendy Widayat (Ed.). Yogyakarta: Ombak.

Herusatoto, B. (2011). Mitologi Jawa. Depok: Oncor.

Indraningsih. (2011). Hermeneutika Paul Ricoeur dan Penerapannya Pada Pemaknaan Simbol Dalam Roman "Rafilus" Karya Budi Darma. Jurnal Filsafat Vol. 21, Nomor 2, Agustus 2011. Yogyakarta: Fakultas Filsafat UGM.

Masinambo, E.K.M. (1997). Koentjaraningrat dan antropologi di Indonesia. Jakarta: Asosiasi Antropologi Indonesia dan Yayasan Obor Indonesia. 
EduLite Journal of English Education, Literature, and Culture Vol. 3, No. 2, August 2018, pp. 188-195

Nugraheni, Intan, \& Dyah, P. (2014). Perilaku Pantang Makanan pada Ibu Nifas di Wilayah Kerja Puskesmas Bayat Klaten Tahun 2014. Jurnal INFOKES Vol. 4, Nomor 2, September 2014.

Swasono, M. F. (1998). Kehamilan, kelahiran, perawatan ibu dan bayi dalam konteks budaya. Jakarta: UI-Press.

Taslim, N. (2013). Kesadaran Alam dan Salingkait Antara Manusia dengan Alam dalam Metos dan Legenda' dalam Folklore dan Folklife. Suwardi Endraswara, Pujiharto, Yoseph Yapi Taum, and Afendy Widayat (Ed.). Yogyakarta: Ombak.

Taum, Y.Y. (2018). Teori-Teori Analisis Sastra Lisan Strukturalisme Levi Strauss. www.academia.edu/3478000/TEORITEORI_ANALISIS_SASTRA_LISAN_STRUKTURALISME_LEVISTRAUSS.

Sugono, D., et al. (2008). Kamus besar Bahasa Indonesia. Jakarta: PT. Gramedia Pustaka Utama.

Werner, E.T.C. (2008). Kumpulan kisah fantastis dan rahasia di baliknya. Translator: Johan Jafardi. Jakarta: PT Gramedia Pustaka Utama.

Zaidan, A.R. et al. (2007). Kamus istilah sastra. Jakarta: Balai Pustaka.

Zaimar, O. K.S. (2015). Metodologi penelitian sastra lisan. Metodologi Kajian Tradisi Lisan. Edisi Revisi. Pudentia MPSS (Ed.) Jakarta: Yayasan Pustaka Obor Indonesia. 